\section{Apple Orchard Productivity and Fruit Quality under Organic, Conventional, and Integrated Management}

\author{
Gregory M. Peck ${ }^{1}$ \\ Department of Horticulture and Landscape Architecture, Washington State \\ University, Pullman, WA 99164-6414 \\ Preston K. Andrews \\ Department of Horticulture and Landscape Architecture, Washington State \\ University, Pullman, WA 99164-6414
}

John P. Reganold

Department of Crop and Soil Sciences, Washington State University, Pullman, WA 99164-6420

John K. Fellman

Department of Horticulture and Landscape Architecture, Washington State University, Pullman, WA 99164-6414

Additional index words. consumer acceptability, controlled atmosphere, flavor volatiles, flesh firmness, Malus domestica, nutrient concentration, shelf life; soluble solids concentration, titratable acidity, total antioxidant activity

Abstract. Located on a 20-ha commercial apple (Malus domestica Borkh.) orchard in the Yakima Valley, Washington, a 1.7-ha study area was planted with apple trees in 1994 in a randomized complete block design with four replications of three treatments: organic (ORG), conventional (CON), and integrated (INT). Soil classification, rootstock, cultivar, plant age, and all other conditions except management were the same on all plots. In years 9 (2002) and 10 (2003) of this study, we compared the orchard productivity and fruit quality of 'Galaxy Gala' apples. Measurements of crop yield, yield efficiency, crop load, average fruit weight, tree growth, color grades, and weight distributions of marketable fruit, percentages of unmarketable fruit, classifications of unmarketable fruit, as well as leaf, fruit, and soil mineral concentrations, were used to evaluate orchard productivity. Apple fruit quality was assessed at harvest and after refrigerated $\left(0\right.$ to $\left.1^{\circ} \mathrm{C}\right)$ storage for three months in regular atmosphere (ambient oxygen levels) and for three and six months in controlled atmosphere $(1.5 \%$ to $2 \%$ oxygen). Fruit internal ethylene concentrations and evolution, fruit respiration, flesh firmness, soluble solids concentration (SSC), titratable acidity (TA), purgeable volatile production, sensory panels, and total antioxidant activity (TAA) were used to evaluate fruit quality. ORG crop yields were two-thirds of the CON and about half of the INT yields in 2002, but about one-third greater than either system in 2003. High ORG yields in 2003 resulted in smaller ORG fruit. Inconsistent ORG yields were probably the result of several factors, including unsatisfactory crop load management, higher pest and weed pressures, lower leaf and fruit tissue nitrogen, and deficient leaf tissue zinc concentrations. Despite production difficulties, ORG apples had 6 to $10 \mathrm{~N}$ higher flesh firmness than CON, and 4 to $7 \mathrm{~N}$ higher than INT apples, for similar-sized fruit. Consumer panels tended to rate ORG and INT apples to have equal or better overall acceptability, firmness, and texture than CON apples. Neither laboratory measurements nor sensory evaluations detected differences in SSC, TA, or the SSC to TA ratio. Consumers were unable to discern the higher concentrations of flavor volatiles found in CON apples. For a $200 \mathrm{~g}$ fruit, ORG apples contained $10 \%$ to $15 \%$ more TAA than CON apples and $8 \%$ to $25 \%$ more TAA than INT apples. Across most parameters measured in this study, the CON and INT farm management systems were more similar to each other than either was to the ORG system. The production challenges associated with low-input organic apple farming systems are discussed. Despite limited technologies and products for organic apple production, the ORG apples in our study showed improvements in some fruit quality attributes that could aid their marketability.

Received for publication 30 June 2005. Accepted for publication 7 Oct. 2005. We thank Peggy Collier, Karen Weller, and D. Scott Mattinson for field and laboratory assistance. Rich Alldredge provided statistical expertise. Harold Ostenson, Mark Hanrahan of Hanrahan Orchards, and Darrin Belton of Wilbur-Ellis Company generously donated their time, knowledge, and equipment. We also thank Kathi Colen Peck, Ines Müller, Ian Merwin, and the anonymous reviewers for their comments. The experimental orchard was located on land owned by Stemilt Growers, Inc. Funding was provided by the U.S. Dept. Agr--NRI Competitive Grants Program and the WSU IMPACT Center. Further support was provided by the WSU Agricultural Research Center.

${ }^{1}$ Former graduate student. Current address: Department of Horticulture, Cornell University, Ithaca, N.Y. 14853. To whom reprint requests should be addressed; e-mail gmp32@cornell.edu.
Increased consumer demand for healthier fruit and more environmentally sustainable farming has driven international growth in the number of producers and land area using organic and integrated farm management systems in apple orchards (Peck et al., 2005). Organic and integrated fruit production systems offer alternatives to conventional apple production systems that use regular applications of broad-spectrum insecticides, which have the potential to adversely affect agroecosystems and the surrounding environment (Aigner etal., 2003), agricultural workers and their families (Curl et al., 2002; Fenske et al., 2000), and the health of consumers (Baker et al., 2002; Curl et al., 2003). In 2003, an estimated 4,047 ha of organically certified apple orchards were farmed in Washington State, representing about $6 \%$ of the total land area producing apples in Washington State. (Granatstein and Kirby, 2002). Apples produced by integrated fruit production methods have yet to attain the same widespread consumer acceptance as organic apples in the U.S. However, in Europe and New Zealand, integrated fruit production has become commonplace displaying the potential for integrated fruit production to expand in the U.S.

Despite the increased production and sales of apples from alternative farming systems, the horticultural performance and fruit quality of organic, conventional, and integrated fruit production systems have not been fully examined in Washington State. Transitional organic and conventional apple orchards have been compared for orchard productivity (i.e., yields, insect and disease pest incidence, mineral concentration, soil quality) in California (Caprile et al., 1994; Swezey et al., 1998; Vossen et al., 1994; Werner, 1997) and at-harvest or postharvest fruit quality of organically and conventionally grown apples have been studied in Canada and Switzerland (DeEll and Prange, 1992, 1993; Weibel et al., 2000). Nutritional quality differences between apple production systems have only been explored by Weibel et al. (2000), who found organically grown apples to have more polyphenols than those grown under an integrated fruit production system. Comparative studies of antioxidants in other perennial horticultural crops have found higher concentrations of polyphenols and other antioxidants in organic pears (Pyrus communis L.) and peaches (Prunus persica L.) (Carbonaro and Mattera, 2001; Carbonaro et al., 2002). However, conventionally grown yellow plums (Prunus domestica L.) had higher concentrations of polyphenols and quercetin than those grown organically, whereas other flavonoids and several vitamins were higher in organic fruit (Lombardi-Boccia et al., 2004).

Since 1994, Washington State University researchers have examined and compared organic (ORG), conventional (CON), and integrated (INT) apple management systems at a single research site on a commercial orchard in the Yakima Valley, Washington. The study site had the same soil classification and soil properties at planting (Glover et al., 2002) and was exposed to a similar microclimate throughout. Variables other than management 
system (i.e., rootstock, cultivar, orchard establishment, tree density, tree training, irrigation, harvest dates, and postharvest handling) were identical among treatments. Previous results from this study identified higher soil quality and lower environmental impacts for the ORG and INT systems compared to the CON system (Glover et al., 2000; Reganold et al., 2001). 'Golden Delicious' apples from the ORG system had similar yields to the CON and INT systems, had equal or better fruit quality, and were the most profitable (Glover et al., 2002; Reganold et al., 2001). The ORG system was also the most energy efficient and had the least negative environmental impact from agrochemical applications (Reganold et al., 2001). Assessed qualitatively, the ORG system ranked first in overall sustainability, followed by the INT, and last by the CON system (Reganold et al., 2001).

The purpose of this continuation of the study was to gain further insights into the effects that ORG, CON, and INT farm management systems have on horticultural and fruit quality parameters. We compared the orchard productivity and fruit quality of apples under these farming systems in years 9 (2002) and 10 (2003) of this long-term study by evaluating tree physiology, yields, and pest and disease damage, as well as fruit size and color grade, fruit physical and flavor properties, and the total antioxidant activity of the apples over the course of several storage and shelf-life regimes. Results from this study highlight the advantages and disadvantages of employing alternative farming systems in apple production.

\section{Materials and Methods}

Study area. Located on a 20-ha commercial, conventional apple orchard in the Yakima Valley (lat. $46^{\circ} 25^{\prime} \mathrm{N}$, long. $120^{\circ} 16^{\prime} \mathrm{W}$ ), the 1.7 -ha study area was planted in 1994 as a randomized complete block design with four replications of three treatments: ORG, CON, and INT (Reganold et al., 2001). The research site was bordered on the north and west by the commercial orchard and by unsprayed pasture on the south and east sides. Each of the 12 experimental plots were 0.14 ha and consisted of 4 rows (spaced $3.2 \mathrm{~m}$ apart) each 80 trees (spaced $1.4 \mathrm{~m}$ apart) long trained on a 3-wire trellis system for a density of 2240 trees/ha. Twelve sample trees randomly selected in the spring of each year from the middle two rows of each experimental plot, excluding 20 trees from each end of the sample row, were used for all evaluations that season. Due to problems with fruit russeting and market demand for newer cultivars, every other tree was top-grafted in 1999 from 'Golden Delicious' to 'Galaxy Gala', with the remaining half grafted in 2000. The rootstock remained EMLA.9, with 'Golden Delicious' as an interstock for each tree.

Farm management treatments. The ORG treatment used only approved organic practices as mandated by the U.S. Dept. of Agriculture (USDA) National Organic Program (Federal Register, 2000) and the Washington State Dept. of Agriculture Organic Food Program(WSDA, 2004). The CON treatment followed practices used for the remainder of the conventional apple blocks on the farm, which reflected the crop protection practices of commercial, conventional apple orchards in Washington State (Martin, 2004). The INT treatment combined practices from both the ORG and CON farm management systems, including integrated pest management (IPM) from both systems and soil-building practices from the
ORG system, in an effort to reduce the use of agrochemicals. A licensed pest control advisor (Wilbur Ellis, Inc., Yakima, Wash.) made pest control recommendations for all three systems based on IPM principles, including modeling, trapping, and monitoring for insects and diseases. The agrochemicals used in each system are indicated in Table 1 for flowering and fruit thinning, weed control, and fertilization. Full bloom at the study site occurred on $18 \mathrm{Apr}$. 2002 and 15 Apr. 2003.

\section{Orchard productivity}

Crop yields and tree growth. Two harvests were conducted each year (130 and $137 \mathrm{~d}$ after full bloom in 2002, and 124 and 127 d after full bloom in 2003). Harvest analyses were conducted on the first harvest in 2002 and on the second harvest in 2003 based on the optimal maturity for 'Gala' apples in each season (Plotto et al., 1995). Calculations of yield, yield efficiency, crop load (number of fruit per tree), average fruit weight, and amount of unmarketable fruit were calculated at each harvest by counting and weighing all of the fruit from each of the 12 sample trees per plot and are reported as the cumulative value of the two harvests in each year. Tree growth was assessed by calculating the trunk crosssectional area (TCSA) from measurements of trunk circumference, assuming a circular geometry, at $20 \mathrm{~cm}$ above the graft union of the rootstock. Return bloom was calculated by floral intensity (ratio of total flower buds to total flower + vegetative buds) on three branches of each sample tree.

Color grade, weight distribution, and cullage analyses. All fruit from both harvests of the 12 samples trees in each experimental plot were brought to the USDA-Agricultural

Table 1. Management practices and agrochemical inputs (except pest and disease control) used in the production of organic (ORG), conventional (CON), and integrated (INT) 'Gala' apples, 2002-03.

\begin{tabular}{lcll}
\hline Practice & Treatment & 2002 & 2003 \\
\hline Flower/fruit thinning & ORG & Calcium polysulfide (1) & Calcium polysulfide + Crocker's Fish Oil + Petroleum oil (2) \\
& CON & Carbaryl (1) & Calcium polysulfide + Crocker's Fish Oil + Petroleum oil (2) \\
& Ethephon + 1 NAA (1) & Carbaryl + 1 NAA (1) \\
& Carbaryl + 1 NAA (1) & Calcium polysulfide + Crocker's Fish Oil + Petroleum oil (2)
\end{tabular}

Ethephon + 1 NAA (1)

Carbaryl + 1 NAA (1)

Weed control $\quad$ ORG

Thermal (2)

Mowing (2)

CON Glyphosate (5)

Diuron (1)

Simazine (1)

Ground fertilization/cover crop $\quad$ ORG

NT Glyphosate (5) NA

Lolium multiflorum

Vicia villosa

Trifolium repens

$\begin{array}{cc} & \text { CON } \\ \text { Foliar fertilization } & \text { INT } \\ \text { ORG }\end{array}$

Chelated calcium (3)

Mechanical tillage (3)
Mowing (1)

$\mathrm{NA}^{\mathrm{z}}$

Zinc sulfate (1)

Calcium chloride (2)

Trifolium repens

Blood meal

Ammonium sulfate

Ammonium sulfate

Pronatural zinc sulfate (2)

Sodium borate (1)

Fish emulsion (1)

CON Zinc sulfate (1) Zinc sulfate (1)

Sodium borate (1)

Calcium chloride (3)

INT Chelated calcium (3)

Pronatural zinc sulfate (2)

Sodium borate (1)

Fish emulsion (1)

${ }^{2}$ Not available. The farm management was reasonably confident that glyphosate was used in the CON and INT systems for weed control.

${ }^{y}$ Number in parenthesis is the number of times the practice or input was conducted in that year. 
Research Service Tree Fruit Research Laboratory (Wenatchee, Wash.), where they were sorted for size (based on the number of apples packed into a 42-lb box) and graded for color using a demonstration model AWETA sorter interfaced to a computer running AWESORT software (v.2.28, Nootdorp, The Netherlands). The sorter was programmed to follow USDA (Federal Register, 1981) and Washington State color and size standards (WAC, 2003). Fruit were separated into those with $\geq 66 \%$ red blush area, those with $33 \%$ to $65 \%$ red blush area, and those with $<33 \%$ red blush area. As fruits were loaded onto the conveyor belt for sorting and grading, each apple was visually inspected for injury and damage as described in WAC 16-403-265 and 16-403-266 (WAC, 2003). These unmarketable apples were not sorted in the AWETA, but brought back to the Fruit Biology Laboratory at Washington State University (WSU) for visual inspection and segregation into cullage categories.

Plant tissue and soil nutrient analyses. Leaf mineral concentrations were analyzed for $\mathrm{N}, \mathrm{P}, \mathrm{K}, \mathrm{S}, \mathrm{Ca}, \mathrm{Mg}, \mathrm{B}, \mathrm{Zn}, \mathrm{Mn}, \mathrm{Cu}$, and $\mathrm{Fe}$ on a dry-weight basis from a pooled sample of 100 midterminal shoot leaves per plot taken from midcanopy height. Fruit mineral concentrations were analyzed for $\mathrm{N}, \mathrm{P}, \mathrm{K}, \mathrm{Ca}$, $\mathrm{Mg}, \mathrm{B}$, and $\mathrm{Zn}$ on a dry-weight basis from a pooled sample of 15 whole fruits from each experimental plot. Samples for both leaf and fruit mineral analyses were collected 2 weeks before harvest and analyzed by commercial laboratories (Soiltest Farm Consultants, Inc., Moses Lake, Wash., in 2002 and Cascade Analytical, Inc., Wenatchee, Wash., in 2003) using standard methods (Gavlak et al., 1994). Pooled soil cores were taken in June 2002 and September 2003 from three random sites midway between trees within the tree-row at depths of 0 to $7.5,7.5$ to 15 , and 15 to $30 \mathrm{~cm}$ in each plot. The samples were analyzed by Soiltest Farm Consultants, Inc., for total N, $\mathrm{NO}_{3}-\mathrm{N}, \mathrm{NH}_{4}-\mathrm{N}, \mathrm{P}, \mathrm{K}, \mathrm{S}, \mathrm{B}, \mathrm{Zn}, \mathrm{Mn}, \mathrm{Cu}, \mathrm{Fe}$, $\mathrm{Ca}, \mathrm{Mg}$, and $\mathrm{Na}$ on a dry-weight basis.

\section{Fruit quality analyses}

Storage and shelf-life treatments. Fruit quality was assessed at harvest and after refrigerated $\left(0\right.$ to $\left.1{ }^{\circ} \mathrm{C}\right)$ storage for 3 months in regular atmosphere (RA3, ambient oxygen levels) and for 3 and 6 months in controlled atmosphere (CA3 and CA6, respectively, $1.5 \%$ to $2 \%$ oxygen). From each experimental plot, medium-sized (161 to $204 \mathrm{~g}$ ) apples with $\geq 66 \%$ red blush were used for analysis at harvest and at each postharvest interval and for all the fruit quality measurements described below. When removed from storage, apples were placed in the laboratory under prevailing temperature conditions (about $22^{\circ} \mathrm{C}$ ) for either $24 \mathrm{~h}$ (Day 1) or, to measure the shelf life, for $7 \mathrm{~d}$ (Day 7 ). These experimental factors comprise each of the fruit quality analyses that follow.

Internal ethylene, ethylene evolution, and fruit respiration. Five apples from each experimental factor were individually analyzed for internal ethylene concentration (IEC) by injecting a $1-\mathrm{mL}$ (2002) or $0.5-\mathrm{mL}$ (2003) gas sample from the core space of a whole apple into a gas chromatograph (model G8A; Shimadzu, Kyoto, Japan, in 2002 and model 5890A; Hewlett-Packard, Palo Alto, Calif., in 2003) (Fellman et al., 2003). Respiration and ethylene evolution were measured from five apples from each experimental plot placed inside Plexiglas chambers supplied with ethylene-free air (Patterson and Apel, 1984).

Instrumental measurements of fruit quality. Ten apples from each experimental factor were individually weighed, ensuring they were of similar size. Flesh firmness was averaged from two measurements taken at the equator of each apple, after removing the peel, with a penetrometer fitted with a cylindrical 11.1mm-diameter head (Apple Maturity Program, 1986). Percent moisture (2003 only) was found by weighing a 2-cm-long cylindrical piece of flesh tissue (no. 9 cork borer, $1.5 \mathrm{~cm}$ in diameter), removed from the equator of 10 apples directly beneath the peel, before and after 24 $\mathrm{h}$ at $80{ }^{\circ} \mathrm{C}$ (Nielsen, 1998). Starch index (SI) was determined by staining the stem side of an equatorial cross-section of the apples with iodine ( $\mathrm{I}_{2}-\mathrm{KI}$ ) solution and visually rating the color change ( $1=100 \%$ staining; $6=0 \%)$ on a 'Gala'-specific SI chart (Cascade Analytical, Inc., Wenatchee, Wash.). A juice aliquot from each apple was taken to measure soluble solids concentration (SSC) using a refractometer (model PR-101; ATAGO, Tokyo, Japan) and reported as ${ }^{\circ}$ Brix. Titratable acidity (TA) was measured by titrating a $10 \mathrm{~mL}$ juice aliquot against a $0.1 \mathrm{~N} \mathrm{KOH}$ solution to an end-point of pH 8.1 (Apple Maturity Program, 1986). A composite juice sample from these 10 apples was used for purgeable volatile analyses (Fellman et al., 1993). The volatile esters (i.e., butyl acetate, hexyl acetate, and 2-methylbutyl acetate) responsible for the distinctive fruity flavor of 'Gala' apples were quantified, as were numerous aldehydes and alcohols (Mattheis et al., 1998; Plotto et al., 1999).

Sensory evaluation of fruit quality. Ten apples from each experimental factor were individually weighed ensuring they were of similar size. Consumer acceptance panels, comprised of 48 untrained individuals, were conducted at the Food Science and Human Nutrition Sensory Laboratory at WSU. Each panelist judged all three treatments from one block separately and in a randomized order, with a total of 12 panelists per block. Unpeeled apples, at room temperature, were quartered and cored. Each quarter was sliced (stem to calyx) into three equal parts, placed on a white plate identified by random code, and immediately served to a panelist. All sessions were conducted in isolated sensory booths under white light.

Total antioxidant activity. By adapting the methods of Cano et al. (1998) and Arnao et al. (2001), TAA was quantified in both peel and flesh tissues of four apples from each experimental factor. Peel tissue was collected from a 4-cm band around the apple's equator by knife. Flesh tissue was collected by removing a 5-mm-thick slice (stem to calyx) from each quarter of the peeled apple. Tissue was finely ground in liquid $\mathrm{N}_{2}$ and stored at -80 ${ }^{\circ} \mathrm{C}$ until analyzed. Hydrophilic (HAA) and lipophilic antioxidant activities (LAA) were measured in both peel and flesh tissues. 2,2'azino-bis-(3-ethylbenzthiazoline-6-sulfonic acid) in the crystallized diammonium salt form (ABTS), 6-hydroxy-2,5,7,8-tetramethylchroman-2-carboxylic acid (Trolox), and horseradish peroxidase (HRP) were obtained from Sigma-Aldrich Chemical Co. (St. Louis, Missouri). 2-(4-morpholino)-ethano suffonic acid(MES) was obtained from FisherScientific (Fair Lawn, N.J.).

Extractions were performed by grinding (T-line Laboratory Stirrer, Montrose, Pa., fitted with a glass pestle) $100 \mathrm{mg}$ of tissue with $700 \mu \mathrm{L}$ of $50 \mathrm{~mm}$ MES (pH 6.0) and $700 \mu \mathrm{L}$ of $100 \%$ ethyl acetate for $45 \mathrm{~s}$ at $0{ }^{\circ} \mathrm{C}$. Samples were then centrifuged at $13,250 \mathrm{~g}$ for $10 \mathrm{~min}$ at $4{ }^{\circ} \mathrm{C}$. The aqueous phase was collected to measure HAA. The organic phase was collected to measure LAA. The reaction medium was mixed in glass cuvettes containing $10 \mu \mathrm{L}$ of $3.3 \mathrm{U} / \mu \mathrm{L}$ HRP, $40 \mu \mathrm{L}$ of $1 \mathrm{~mm} \mathrm{H} \mathrm{O}_{2}, 100 \mu \mathrm{L}$ of $15 \mathrm{mM} \mathrm{ABTS}$, and either $830 \mu \mathrm{L}$ (for peel) or $810 \mu \mathrm{L}$ (for flesh) of either $50 \mathrm{~mm} \mathrm{NaPO}$ ( $\mathrm{pH} 7.5$ ) (for HAA) or $100 \%$ ethanol (for LAA). The reaction was monitored at $734 \mathrm{~nm}$ on a HP 8453 UV-visible spectrophotometer interfaced to a computer running UV-Visible ChemStation software(v.A.08.03 [71], Agilent Technologies, Avondale, Pa.). When a stable absorbance was obtained, $20 \mu$ Lof peel extract or $40 \mu \mathrm{L}$ of flesh extract was added to the reaction medium and the change in absorbance was measured after $180 \mathrm{~s}$. A Trolox solution was prepared daily to determine standard curves. TAA is the total of HAA + LAA and is expressed as $\mu \mathrm{mol} \mathrm{TAA} / \mathrm{g}$ fresh weight. Since apples contain considerably more flesh than peel tissue, an estimate of TAA for a 200 $\mathrm{g}$ apple was calculated. Based on a 10-fruit sample, a $200 \mathrm{~g}$ 'Gala' apple, minus the core tissue, contained on average $16 \mathrm{~g}$ of edible peel tissue and $154.4 \mathrm{~g}$ of edible flesh tissue.

Statistical analyses. Orchard productivity and harvest fruit quality data were analyzed as a randomized complete block design. Mean separation was by Fisher's protected least significant difference (LSD) at the 5\% level of probability. Harvest and postharvest fruit quality characteristics were analyzed independently. Postharvest evaluations were analyzed as a split-split plot where the main effect was the farm management treatment (ORG, CON, INT), the first split was the storage treatment (RA3, CA3, CA6), and the second split was the shelf-life treatment (Day 1, Day 7). There was no Day 1 treatment for TAA analysis and a split-plot model was used that included the harvest data. All data were subjected to an analysis of variance (ANOVA) using the SAS System for Windows (v.8.01, Cary, North Carolina).

\section{Results}

\section{Orchard productivity}

Crop yields and tree growth. On the basis of fruit weight per hectare, fruit weight per TCSA, and fruit number per TCSA, the CON system yielded the most apples in 2002, followed by the INT, then the ORG systems 
Table 2. Crop yields, yield efficiency, crop density, floral intensity, trunk cross-sectional area (TCSA), average fruit weight, and percent of unmarketable fruit in organic (ORG), conventional (CON), and integrated (INT) 'Gala' apple farm management systems, 2002-03.

\begin{tabular}{|c|c|c|c|c|c|c|}
\hline \multirow[b]{2}{*}{ Parameter } & \multicolumn{3}{|c|}{2002} & \multicolumn{3}{|c|}{2003} \\
\hline & ORG & $\mathrm{CON}$ & INT & ORG & $\mathrm{CON}$ & INT \\
\hline Yield $\left({\left.\mathrm{Mg} \cdot h \mathrm{~h}^{-1}\right)}\right.$ & $15.28 \mathrm{c}^{\mathrm{z}}$ & $46.28 \mathrm{a}$ & $30.13 \mathrm{~b}$ & $56.50 \mathrm{a}$ & $35.70 \mathrm{~b}$ & $36.96 \mathrm{~b}$ \\
\hline $\begin{array}{l}\text { Yield efficiency } \\
\left(\mathrm{kg} \cdot \mathrm{cm}^{-2} \mathrm{TCSA}\right)\end{array}$ & $0.14 \mathrm{c}$ & $0.40 \mathrm{a}$ & $0.25 \mathrm{~b}$ & $0.49 \mathrm{a}$ & $0.29 \mathrm{~b}$ & $0.30 \mathrm{~b}$ \\
\hline $\begin{array}{l}\text { Crop density } \\
\left.\text { (no. of fruit } / \mathrm{cm}^{2} \mathrm{TCSA}\right)\end{array}$ & $0.80 \mathrm{c}$ & $2.43 \mathrm{a}$ & $1.64 \mathrm{~b}$ & $3.23 \mathrm{a}$ & $1.59 \mathrm{~b}$ & $1.57 \mathrm{~b}$ \\
\hline $\begin{array}{l}\text { Floral intensity } \\
\text { (flower buds to total buds) }\end{array}$ & $0.29 \mathrm{c}$ & $0.67 \mathrm{a}$ & $0.45 \mathrm{~b}$ & $0.81 \mathrm{a}$ & $0.59 \mathrm{c}$ & $0.68 \mathrm{~b}$ \\
\hline $\operatorname{TCSA}\left(\mathrm{cm}^{2}\right)$ & $43.9 \mathrm{~b}$ & $48.3 \mathrm{a}$ & $44 \mathrm{ab}$ & $54.3 \mathrm{~b}$ & $60.7 \mathrm{a}$ & $58.6 \mathrm{ab}$ \\
\hline Average fruit weight $(\mathrm{kg})$ & $0.176 \mathrm{a}$ & $0.168 \mathrm{~b}$ & $0.164 \mathrm{~b}$ & $0.158 \mathrm{~b}$ & $0.188 \mathrm{a}$ & $0.196 \mathrm{a}$ \\
\hline Unmarketable culls (\%) & $\mathrm{ND}^{\mathrm{y}}$ & ND & ND & $42 \mathrm{a}$ & $33 \mathrm{a}$ & $31 \mathrm{a}$ \\
\hline
\end{tabular}

${ }^{2}$ Differences among treatments within each year followed by different letters are significant at the 0.05 level (LSD).

y No data were collected.

Table 3. Average leaf mineral concentrations of organic (ORG), conventional (CON), and integrated (INT) 'Gala' apple farm management systems, 2002-03.

\begin{tabular}{|c|c|c|c|c|c|c|c|}
\hline \multirow[b]{2}{*}{ Parameter } & \multicolumn{3}{|c|}{2002} & \multicolumn{3}{|c|}{2003} & \multirow[b]{2}{*}{$\mathrm{CNR}^{\mathrm{y}}$} \\
\hline & ORG & $\mathrm{CON}$ & INT & $\overline{\mathrm{ORG}}$ & $\mathrm{CON}$ & INT & \\
\hline Total N (\%) & $2.46 b^{z}$ & $2.67 \mathrm{a}$ & $2.67 \mathrm{a}$ & $2.44 \mathrm{a}$ & $2.54 \mathrm{a}$ & $2.61 \mathrm{a}$ & $1.7-2.0$ \\
\hline $\mathrm{P}(\%)$ & $0.24 \mathrm{a}$ & $0.23 \mathrm{a}$ & $0.22 \mathrm{a}$ & $0.22 \mathrm{a}$ & $0.18 \mathrm{~b}$ & $0.19 \mathrm{~b}$ & $<0.1$ \\
\hline $\mathrm{K}(\%)$ & $1.53 \mathrm{a}$ & $1.63 \mathrm{a}$ & $1.66 \mathrm{a}$ & $1.49 \mathrm{a}$ & $1.48 \mathrm{a}$ & $1.55 \mathrm{a}$ & $0.8-1.5$ \\
\hline $\mathrm{S}(\%)$ & $0.15 \mathrm{c}$ & $0.20 \mathrm{a}$ & $0.18 \mathrm{~b}$ & $0.19 \mathrm{~b}$ & $0.21 \mathrm{a}$ & $0.20 \mathrm{ab}$ & $0.01-0.025$ \\
\hline $\mathrm{Ca}(\%)$ & $1.30 \mathrm{~b}$ & $1.94 \mathrm{a}$ & $1.62 \mathrm{~b}$ & $1.94 \mathrm{a}$ & $2.00 \mathrm{a}$ & $1.79 \mathrm{a}$ & $<1.2$ \\
\hline $\operatorname{Mg}(\%)$ & $0.25 \mathrm{~b}$ & $0.33 \mathrm{a}$ & $0.31 \mathrm{a}$ & $0.33 \mathrm{a}$ & $0.36 \mathrm{a}$ & $0.35 \mathrm{a}$ & $0.2-0.3$ \\
\hline $\mathrm{B}(\mathrm{ppm})$ & $23.25 \mathrm{a}$ & $24.50 \mathrm{a}$ & $25.00 \mathrm{a}$ & $28.00 \mathrm{a}$ & $24.50 \mathrm{~b}$ & $27.00 \mathrm{ab}$ & $20-25$ \\
\hline $\mathrm{Zn}(\mathrm{ppm})$ & $11.50 \mathrm{c}$ & $20.25 \mathrm{a}$ & $17.00 \mathrm{~b}$ & $17.25 \mathrm{a}$ & $17.75 \mathrm{a}$ & $17.50 \mathrm{a}$ & $15-20$ \\
\hline $\mathrm{Mn}(\mathrm{ppm})$ & $48.50 \mathrm{~b}$ & $106.25 \mathrm{a}$ & $95.00 \mathrm{a}$ & $49.75 \mathrm{~b}$ & $81.50 \mathrm{a}$ & $46.75 \mathrm{~b}$ & $25-30$ \\
\hline $\mathrm{Cu}(\mathrm{ppm})$ & $7.25 \mathrm{~b}$ & $7.75 \mathrm{ab}$ & $8.50 \mathrm{a}$ & $7.25 \mathrm{a}$ & $6.25 \mathrm{~b}$ & $7.75 \mathrm{a}$ & $5-6$ \\
\hline $\mathrm{Fe}(\mathrm{ppm})$ & $265.25 \mathrm{a}$ & $238.75 \mathrm{a}$ & $262.75 \mathrm{a}$ & $128.25 \mathrm{a}$ & $101.00 \mathrm{~b}$ & $117.75 \mathrm{ab}$ & $<100$ \\
\hline
\end{tabular}

${ }^{2}$ Differences among treatments within each year followed by different letters are significant at the 0.05 level (LSD).

${ }^{y}$ Critical nutrient range (CNR) for mid-terminal apple leaves as defined by Dow (1980) to be the range of concentrations above which the crop is amply supplied and below which the crop is deficient.

Table 4. Average fruit mineral concentrations of organic (ORG), conventional (CON), and integrated (INT) 'Gala' apple farm management systems, 2002-03.

\begin{tabular}{|c|c|c|c|c|c|c|}
\hline \multirow[b]{2}{*}{ Parameter } & \multicolumn{3}{|c|}{2002} & \multicolumn{3}{|c|}{2003} \\
\hline & ORG & $\mathrm{CON}$ & INT & ORG & $\mathrm{CON}$ & INT \\
\hline Total N (\%) & $0.25 \mathrm{~b}^{\mathrm{z}}$ & $0.27 \mathrm{ab}$ & $0.29 \mathrm{a}$ & $0.31 \mathrm{c}$ & $0.41 \mathrm{a}$ & $0.35 \mathrm{~b}$ \\
\hline $\mathrm{P}(\%)$ & $0.07 \mathrm{a}$ & $0.07 \mathrm{a}$ & $0.07 \mathrm{a}$ & $0.08 \mathrm{a}$ & $0.09 \mathrm{a}$ & $0.08 \mathrm{a}$ \\
\hline $\mathrm{K}(\%)$ & $0.85 \mathrm{a}$ & $0.87 \mathrm{a}$ & $0.88 \mathrm{a}$ & $0.84 \mathrm{~b}$ & $0.91 \mathrm{a}$ & $0.86 \mathrm{ab}$ \\
\hline $\mathrm{Ca}(\%)$ & $0.03 \mathrm{ab}$ & $0.04 \mathrm{a}$ & $0.03 \mathrm{~b}$ & $0.03 \mathrm{a}$ & $0.03 \mathrm{a}$ & $0.03 \mathrm{a}$ \\
\hline $\operatorname{Mg}(\%)$ & $0.04 \mathrm{a}$ & $0.04 \mathrm{a}$ & $0.04 \mathrm{a}$ & $0.03 \mathrm{a}$ & $0.03 \mathrm{a}$ & $0.03 \mathrm{a}$ \\
\hline $\mathrm{B}(\mathrm{ppm})$ & $11.75 \mathrm{a}$ & $10.50 \mathrm{a}$ & $10.75 \mathrm{a}$ & $17.60 \mathrm{a}$ & $12.93 \mathrm{~b}$ & $17.33 \mathrm{a}$ \\
\hline $\mathrm{Zn}(\mathrm{ppm})$ & $4.50 \mathrm{a}$ & $7.00 \mathrm{a}$ & $5.25 \mathrm{a}$ & $1.08 \mathrm{a}$ & $0.98 \mathrm{a}$ & $0.90 \mathrm{a}$ \\
\hline $\mathrm{N}$ to $\mathrm{Ca}$ ratio & $8.25 \mathrm{~b}$ & $7.34 \mathrm{~b}$ & $10.67 \mathrm{a}$ & $11.05 \mathrm{~b}$ & $13.90 \mathrm{a}$ & $11.99 \mathrm{~b}$ \\
\hline $\mathrm{Mg}$ to $\mathrm{Ca}$ ration & $1.33 \mathrm{a}$ & $1.17 \mathrm{a}$ & $1.50 \mathrm{a}$ & $1.12 \mathrm{a}$ & $1.14 \mathrm{a}$ & $1.13 \mathrm{a}$ \\
\hline $\mathrm{N}$ to $\mathrm{P}$ ratio & $3.54 \mathrm{a}$ & $3.93 \mathrm{a}$ & $3.96 \mathrm{a}$ & $3.91 \mathrm{a}$ & $4.80 \mathrm{a}$ & $4.40 \mathrm{a}$ \\
\hline $\mathrm{Mg}+\mathrm{K}$ to Ca ratio & $29.58 \mathrm{ab}$ & $25.46 \mathrm{~b}$ & $34.54 \mathrm{a}$ & $30.89 \mathrm{a}$ & $32.07 \mathrm{a}$ & $30.64 \mathrm{a}$ \\
\hline
\end{tabular}

${ }^{2}$ Differences among treatments within each year followed by different letters are significant at the 0.05 level (LSD).

Table 5. Starch index (SI) and internal ethylene concentrations (IEC) for 'Gala' apples in organic (ORG), conventional (CON), and integrated (INT) farm management systems at harvest, after refrigerated storage in regular atmosphere for three months (RA3) and controlled atmosphere for 3 (CA3) and 6 (CA6) months, 2002-03.

\begin{tabular}{|c|c|c|c|c|c|c|}
\hline \multirow[b]{2}{*}{ Parameter } & \multicolumn{3}{|c|}{2002} & \multicolumn{3}{|c|}{2003} \\
\hline & ORG & $\mathrm{CON}$ & INT & ORG & $\mathrm{CON}$ & INT \\
\hline SI first harvest & $4.0 \mathrm{~b}^{\mathrm{z}}$ & $4.3 \mathrm{ab}$ & $4.5 \mathrm{a}$ & $3.5 \mathrm{~b}$ & $4.3 \mathrm{a}$ & $3.5 \mathrm{~b}$ \\
\hline SI main harvest & $4.1 \mathrm{a}$ & $4.3 \mathrm{a}$ & $4.5 \mathrm{a}$ & $4.4 \mathrm{~b}$ & $4.8 \mathrm{a}$ & $4.4 \mathrm{~b}$ \\
\hline IEC main harvest (ppm) & $3.1 \mathrm{a}$ & $1.1 \mathrm{a}$ & $2.5 \mathrm{a}$ & $0.2 \mathrm{~b}$ & $0.8 \mathrm{a}$ & $1.1 \mathrm{a}$ \\
\hline IEC RA3 (ppm) & $49.7 \mathrm{~b}$ & $99.1 \mathrm{ab}$ & $131.2 \mathrm{a}$ & $28.4 \mathrm{~b}$ & $47.8 \mathrm{a}$ & $35.8 \mathrm{~b}$ \\
\hline IEC CA3 (ppm) & $9.4 \mathrm{~b}$ & $29.0 \mathrm{a}$ & $32.4 \mathrm{a}$ & $2.5 \mathrm{a}$ & $2.2 \mathrm{a}$ & $3.9 \mathrm{a}$ \\
\hline IEC CA6 (ppm) & $5.1 \mathrm{~b}$ & $16.4 \mathrm{a}$ & $10.8 \mathrm{ab}$ & $0 \mathrm{a}$ & $0 \mathrm{a}$ & $0 \mathrm{a}$ \\
\hline
\end{tabular}

${ }^{2}$ Differences among treatments within each year followed by different letters are significant at the 0.05 level (LSD).

(Table 2). In 2003, ORG yields were greater than both CON and INT yields (Table 2). Floral intensity mostly followed yield patterns (Table
2), with greater floral intensity resulting in higher yields. In Spring 2002, CON trees had larger TCSAs than ORG trees (Table 2). No differences were seen among farming systems in percent change in TCSA during the 2-year study, and so by the end of 2003 CON trees were still larger than ORG trees (Table 2). The ORG system had the largest average fruit weight in 2002 and the smallest average fruit weight in 2003 (Table 2).

Color grade, weight distribution, and cullage analyses. Despite differences in average fruit weight in 2002, no differences existed among farming systems in fruit weight distributions (Peck, 2004). Nevertheless, ORG fruit were skewed toward smaller weight classes $(\leq 160 \mathrm{~g})$ in 2003 , with less ORG fruit in the middle and larger classes $(\geq 161 \mathrm{~g})$ (Peck, 2004). There were no treatment differences for color grade in either year, with $>85 \%$ of apples in the highest color grade ( $\geq 66 \%$ red blush). ORG fruit had significantly more codling moth (Cydia pomonella L.) damage in 2002, but no differences occurred for overall pest damage (which includes codling moth), because the western flower thrip (Frankliniella occidentalis Pergande) caused more damage to CON and INT fruit (Peck, 2004). Although there were no differences in overall percent unmarketable fruit in 2003 (Table 2) and despite identical insecticide applications in the ORG and INT systems, there were more apples damaged by insects other than codling moth in the ORG system than in the CON or INT systems (Peck, 2004).

Plant tissue and soil nutrient analyses. Leaf $\mathrm{N}$ concentrations were slightly higher in the CON and INT systems in 2002, but no difference was measured in 2003 (Table 3). In both years, all three systems were above the critical nutrient range (CNR) for mature apple trees (Table 3). In 2002, zinc (Zn) levels were highest in CON leaf tissue and lowest in ORG leaf tissue, but no differences were found in 2003 (Table 3). ORG trees were Zn deficient in 2002 (Table 3) with visible symptoms, including small thin chlorotic leaves, leaf rosetting, and branches with sections of nonbearing blind wood (Martin, 2004; Swietlik, 2002), observed in both years. There were no symptoms of $\mathrm{Zn}$ deficiency in the CON or INT systems. In 2003, leafboron (B) concentrations were greater in ORG than CON trees (Table 3 ). Although no B was applied from 2000 to 2002 , all three systems were within or above the CNR in 2002 and 2003 (Table 3). Leaf manganese $(\mathrm{Mn})$ levels were considerably lower in the ORG system in 2002 and in the ORG and INT systems in 2003 (Table 3), but in both years all three treatments were within or above the CNR. All other leaf mineral nutrient levels were within or above the CNR (Table 3 ), therefore statistical differences among them may not be physiologically important.

Fruit tissue $\mathrm{N}$ levels were higher in INT apples than ORG apples in 2002, and highest in CON apples and lowest in ORG apples in 2003 (Table 4). The $\mathrm{N}$ to $\mathrm{Ca}$ ratio was lower for ORG apples than INT apples in 2002 and than CON apples in 2003, reflecting the lower $\mathrm{N}$ status of the ORG fruit. No Zn or B differences were found in fruit tissue samples in 2002, but in 2003 fruit B concentration was higher in the ORG and INT apples than the 
CON apples (Table 4), similar to the pattern for leaf tissue (Table 3 ). No observable symptoms of $\mathrm{Zn}$ or B deficiency were observed in fruit in either year.

Soil nutrient analyses for total $\mathrm{N}, \mathrm{NO}_{3}-\mathrm{N}$, and extractable $\mathrm{P}$ were all within thresholds developed by Glover et al. (2000). There were no other consistent differences in any other soil nutrient (Peck, 2004).

\section{Fruit quality analyses}

Harvest maturity. Since maturity at harvest greatly affects apple fruit quality, fruit were assessed for IEC and starch hydrolysis indices (Table 5), both good predictors of acceptable maturity for 'Gala' apples (Mattheis et al., 1998; Plotto et al., 1995). Few differences in these measures of fruit maturity were found among farming systems in 2002. In 2003, however, IEC was higher for CON and INT apples at harvest, but SI indicated sufficient starch hydrolysis in fruit of all three systems (Table 5). In addition, fruit ethylene evolution and respiration rates were similar among systems at harvest in both years (Peck, 2004). It is reasonable to assume that fruit from all three treatments were harvested at similar maturities, and therefore, fruit quality differences are due to farming system and not maturity effects.

There were seasonal differences in maturity, however, because apples from all three systems had higher IECs in 2002 than in 2003 (Table 5 ). This is common in apple production, where seasonal differences in climate and crop load can greatly affect harvest maturity. In both years, the IEC was several times higher in apples emerging from RA3 than from either CA3 or CA6, and at CA3 the IEC was higher than at CA6 (Table 5). Lower IEC at CA6 is typical for 'Gala' apples, which tend to lose viability after prolonged storage (Plotto et al., 1995), making fruit quality differences after 6 months storage a significant finding. The IEC also differed among farming systems after storage. In 2002, ORG apples had lower IECs than either CON or INT apples for CA3, and lower IECs than INT apples for RA3 and CON apples for CA6 (Table 5). In 2003, ORG and INT apples had lower IEC than CON apples for RA3 (Table 5).

Instrumental measurements of fruit quality. At harvest, ORG and CON apples were firmer than INT apples in 2002, whereas ORG and INT apples were firmer than CON apples in 2003 (Table 6). Overall, ORG apples from the storage treatments in 2002 were $6.51 \mathrm{~N}$ firmer than CON apples and 7.38 N firmer than INT apples (Fig. 1A). Overall, ORG apples from the storage treatments in 2003 were $11.2 \mathrm{~N}$ firmer than $\mathrm{CON}$ and $5.75 \mathrm{~N}$ firmer than INT apples (Fig. 1A).

The SSC was higher in ORG apples than both CON and INT apples at harvest in 2002 (Table 6), but CON apples had higher SSC than ORG apples at the 2003 harvest (Table 6). After storage, there were no consistent farm system effects for SSC in 2002 (Peck, 2004). In 2003, an interaction between farm management $\times$ shelf-life treatments revealed that CON apples had consistently greater SSC than ORG and INT apples before and after the seven-day shelf-life interval and INT apples had greater SSC than ORG apples after $7 \mathrm{~d}$ (Peck, 2004). This interaction also showed that SSC increased from day 1 to day 7 of the

shelf-life trial in CON and INT apples (Peck, 2004), likely due to starch hydrolysis.

There were no farm system differences in TA at harvest in 2002, but INT apples had

Table 6. Flesh firmness, soluble solid concentration (SSC), titratable acidity (TA), and the ratio of SSC to TA of apples from organic (ORG), conventional (CON), and integrated (INT) farm management systems at harvest, 2002-03.

\begin{tabular}{lccccccc}
\hline Analytical & \multicolumn{3}{c}{2002} & & \multicolumn{3}{c}{2003} \\
\cline { 2 - 4 } measurement & ORG & CON & INT & & ORG & CON & INT \\
\hline Firmness $(\mathrm{N})$ & $78.59 \mathrm{a}^{\mathrm{z}}$ & $77.77 \mathrm{a}$ & $71.96 \mathrm{~b}$ & & $82.15 \mathrm{a}$ & $72.82 \mathrm{~b}$ & $81.35 \mathrm{a}$ \\
SSC $\left({ }^{\circ}\right.$ Brix $)$ & $14.5 \mathrm{a}$ & $14.1 \mathrm{~b}$ & $14.0 \mathrm{~b}$ & & $11.8 \mathrm{~b}$ & $12.4 \mathrm{a}$ & $12.3 \mathrm{ab}$ \\
TA $(\%)$ & $0.60 \mathrm{a}$ & $0.58 \mathrm{a}$ & $0.51 \mathrm{a}$ & & $0.36 \mathrm{~b}$ & $0.36 \mathrm{~b}$ & $0.39 \mathrm{a}$ \\
SSC to TA ratio & $24.2 \mathrm{~b}$ & $24.8 \mathrm{~b}$ & $27.8 \mathrm{a}$ & & $33.0 \mathrm{ab}$ & $34.4 \mathrm{a}$ & $31.4 \mathrm{~b}$ \\
\hline
\end{tabular}

${ }^{\mathrm{z}}$ Differences among treatments within each year followed by different letters are significant at the 0.05 level (LSD).

(A)

(D)

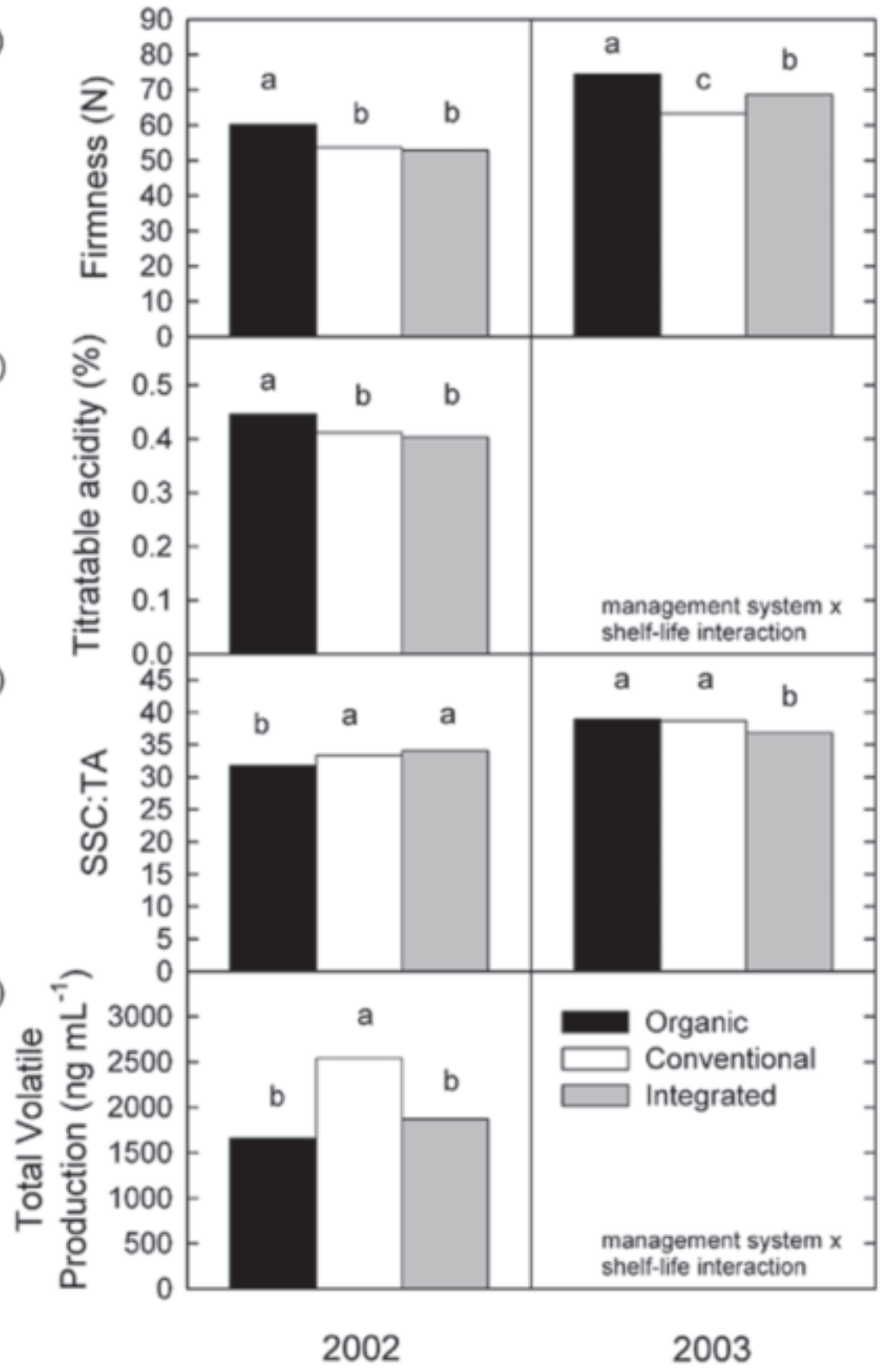

Fig. 1. Main effect means for 'Gala' apple flesh firmness in 2002 and 2003 (A), titratable acidity in 2002 (B), the ratio of soluble solids concentration to titratable acidity (SSC:TA) in 2002 and 2003 (C), and total volatile production in 2002 (D) from organic, conventional, and integrated farm management systems pooling all storage and shelf-life treatments. Differences among treatments within each year followed by different letters are significant at the 0.05 level (LSD). 
Table 7. Purgeable volatile concentrations of apples from organic (ORG), conventional (CON), and integrated (INT) farm management systems at harvest, 2002-03.

\begin{tabular}{lrrrrrrr}
\hline & \multicolumn{3}{c}{2002} & & \multicolumn{3}{c}{2003} \\
\cline { 2 - 3 } \cline { 7 - 8 } Chemical classification & \multicolumn{1}{c}{ ORG } & \multicolumn{1}{c}{ CON } & \multicolumn{1}{c}{ INT } & & ORG & \multicolumn{1}{c}{ CON } & \multicolumn{1}{c}{ INT } \\
\hline Alcohols $\left(\mathrm{ng} \cdot \mathrm{mL}^{-1}\right)$ & $453.1 \mathrm{a}^{2}$ & $417.5 \mathrm{a}$ & $583.9 \mathrm{a}$ & & $220.4 \mathrm{a}$ & $514.4 \mathrm{a}$ & $315.8 \mathrm{a}$ \\
Aldehydes $\left(\mathrm{ng} \cdot \mathrm{mL}^{1}\right)$ & $179.5 \mathrm{a}$ & $95.3 \mathrm{~b}$ & $104.3 \mathrm{~b}$ & & $525.3 \mathrm{a}$ & $532.1 \mathrm{a}$ & $396.3 \mathrm{a}$ \\
Esters $\left(\mathrm{ng} \cdot \mathrm{mL}^{-1}\right)$ & $486.8 \mathrm{a}$ & $633.9 \mathrm{a}$ & $626.7 \mathrm{a}$ & & $727.2 \mathrm{~b}$ & $1524.9 \mathrm{a}$ & $570.6 \mathrm{~b}$ \\
Total volatiles $\left(\mathrm{ng} \cdot \mathrm{mL}^{-1}\right)$ & $1123.2 \mathrm{a}$ & $1149.5 \mathrm{a}$ & $1318.2 \mathrm{a}$ & & $1476.5 \mathrm{~b}$ & $2576.8 \mathrm{a}$ & $1286.7 \mathrm{~b}$ \\
\hline
\end{tabular}

${ }^{2}$ Differences among treatments within each year followed by different letters are significant at the 0.05 level (LSD).

Table 8. Consumer sensory panel ratings of apples from organic (ORG), conventional (CON), and integrated (INT) apple farm management systems at harvest, 2002-03.

\begin{tabular}{|c|c|c|c|c|c|c|}
\hline \multirow[b]{2}{*}{ Measurement } & \multicolumn{3}{|c|}{2002} & \multicolumn{3}{|c|}{2003} \\
\hline & $\overline{\mathrm{ORG}}$ & $\mathrm{CON}$ & INT & ORG & $\mathrm{CON}$ & INT \\
\hline$\overline{\text { Overally }}^{y}$ & $6.8 \mathrm{a}^{2}$ & $6.7 \mathrm{a}$ & $7.0 \mathrm{a}$ & $6.2 \mathrm{~b}$ & $6.5 \mathrm{ab}$ & $6.8 \mathrm{a}$ \\
\hline Texture $^{y}$ & $6.8 \mathrm{a}$ & $6.8 \mathrm{a}$ & $6.9 \mathrm{a}$ & $6.5 \mathrm{a}$ & $6.3 \mathrm{a}$ & $6.7 \mathrm{a}$ \\
\hline Flavor $^{y}$ & $6.6 \mathrm{a}$ & $6.5 \mathrm{a}$ & $6.8 \mathrm{a}$ & $5.9 \mathrm{a}$ & $6.2 \mathrm{a}$ & $6.5 \mathrm{a}$ \\
\hline Firmness $^{\mathrm{x}}$ & $6.6 \mathrm{a}$ & $6.4 \mathrm{a}$ & $6.2 \mathrm{a}$ & $6.8 \mathrm{a}$ & $6.1 \mathrm{~b}$ & $6.4 \mathrm{ab}$ \\
\hline Sweetness $^{x}$ & $5.6 \mathrm{a}$ & $5.8 \mathrm{a}$ & $6.0 \mathrm{a}$ & $5.0 \mathrm{~b}$ & $5.8 \mathrm{a}$ & $5.6 \mathrm{ab}$ \\
\hline Tartness $^{\mathrm{x}}$ & $4.7 \mathrm{a}$ & $4.3 \mathrm{a}$ & $4.4 \mathrm{a}$ & $4.9 \mathrm{a}$ & $4.5 \mathrm{a}$ & $4.6 \mathrm{a}$ \\
\hline
\end{tabular}

${ }^{2}$ Differences among treatments within each year followed by different letters are significant at the 0.05 level (LSD).

'Based on a 9-point hedonic scale.

${ }^{x}$ Based on a 9-point intensity scale.
greaterTAthan ORG and CON apples at harvest in 2003 (Table 6). In the 2002 storage trials, ORG apples had the most TA (Fig. 1B). In 2003, an interaction between farm management $\times$ shelf-life treatments revealed that $\mathrm{CON}$ and INT apples had higher TA after the 7-d shelf life than ORG apples, and that TA declined in fruit from all three farm systems during the shelf-life interval (Peck, 2004).

At harvest in 2002, INT apples had the highest SSC to TA ratio, but in 2003, CON apples were consistently higher than INT apples, with ORG apples being intermediate (Table 6). During the storage trials in $2002, \mathrm{CON}$ and INT apples had higher SSC to TA ratios than ORG apples, whereas ORG and CON apples had higher SSC to TA ratios than INT apples in storage in 2003 (Fig. 1C). Despite the high $\mathrm{SSC}$ to TA ratio for CON apples in both years, no clear pattern of differences emerged for ORG or INT apples. duced from ORG apples at harvest in 2002, no differences among farming systems were noted for alcohols, esters, or total volatile production (Table 7). After storage in 2002, CON fruit produced the most total volatiles (Fig. 1D). The 2003 harvest measurements of volatile production also showed greater CON apples (Table 7). No consistent results were found for esters or aldehydes during the 2002 storage trials because of three-way (farm management $\times$ storage $\times$ shelf life) interactions (Peck, 2004). In the 2003 storage trials, interactions between farm management $\times$ storage treatments occurred for ester and total volatile production, with $\mathrm{CON}$ apples producing more esters at RA 3 and CA3 and more total volatiles at RA3 than fruit from the other systems (Peck, 2004).

Sensory evaluation of fruit quality. At harvest in 2002, consumers detected no differences in any of the rated sensory attributes. For the 2003 harvest, consumers rated INT apples more acceptable than ORG apples, ORG apples
While there were more aldehydes proconcentrations of esters and total volatiles in
3A). ORG fruit also had greater LAA than INT apples (Fig. 3A). In 2003, ORG fruit had greater HAA than CON fruit, and greater peel TAA and total TAA than CON and INT fruit (Fig. 3B). In 2002 , a $200 \mathrm{~g}$ ORG apple had $15 \%$ greater TAA $(965 \mu \mathrm{mol})$ in its edible portion than a CON apple $(825 \mu \mathrm{mol})$ and $25 \%$ greater TAA than an INT apple $(726 \mu \mathrm{mol})$. For the same size apple in 2003, ORG fruit had $10 \%$ greater TAA $(1002 \mu \mathrm{mol})$ than CON $(899 \mu \mathrm{mol})$ and $8 \%$ greater TAA than INT $(926 \mu \mathrm{mol})$ apples. In $2002, \mathrm{CON}$ apples had $12 \%$ greater TAA in the edible portion of a $200 \mathrm{~g}$ apple than INT apples, but in 2003 , INT apples had $3 \%$ greater TAA than CON fruit.

\section{Discussion}

Orchard productivity. Since ORGyields and yield efficiency varied greatly between years on smaller trees (Table 2), it is unlikely that tree size alone accounted for the differences in yields. Fruit size differences were not surprising, since trees with loweryield efficiencies and crop densities tended to produce larger fruit, as was evident for ORG trees in 2002. Lower yields in the ORG system were also noted in the early years of this study when the trees first came into bearing. After 5 years (1994 to 1999) of production, however, there were no differences in cumulative yields or TCSA (Reganold et al., 2001). Biennial bearing due to the lack of effective, certified chemical thinners has been cited as one of the most pressing technological barriers for organic apple production (Glover etal., 2000; Reganold et al., 2001; Swezey et al., 1998; Vossen et al., 1994) and may have contributed to the irregular ORG yields reported here.

ORG yields increased 2.3 times from 2002 to 2003 (Table 2), indicating that this system was likely in a biennial bearing pattern. Although chemical flower thinning occurred for all three systems in both years (Table 1), chemical postbloom thinners are still under development for organic apple production and were only used for the CON and INT system in 2002 and the CON system in 2003. All three systems had additional fruit hand-thinned ruit had greater HAA, peel TAA, flesh and total TAA than CON and INT apples (Fig.

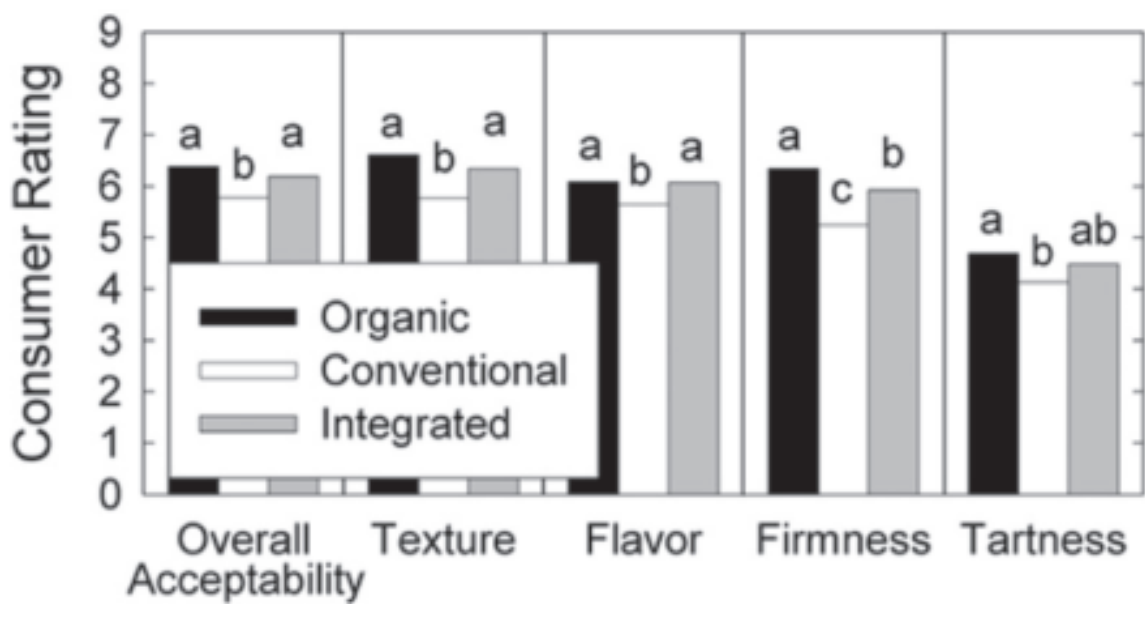

Fig. 2. Main effect means in 2003 for consumer panel evaluations of overall acceptability, texture, flavor, firmness, and tartness of 'Gala' apples from organic, conventional, and integrated farm management systems pooling all storage and shelf-life treatments. Differences within a measurement among treatments followed by different letters are significant at the 0.05 level (LSD). 


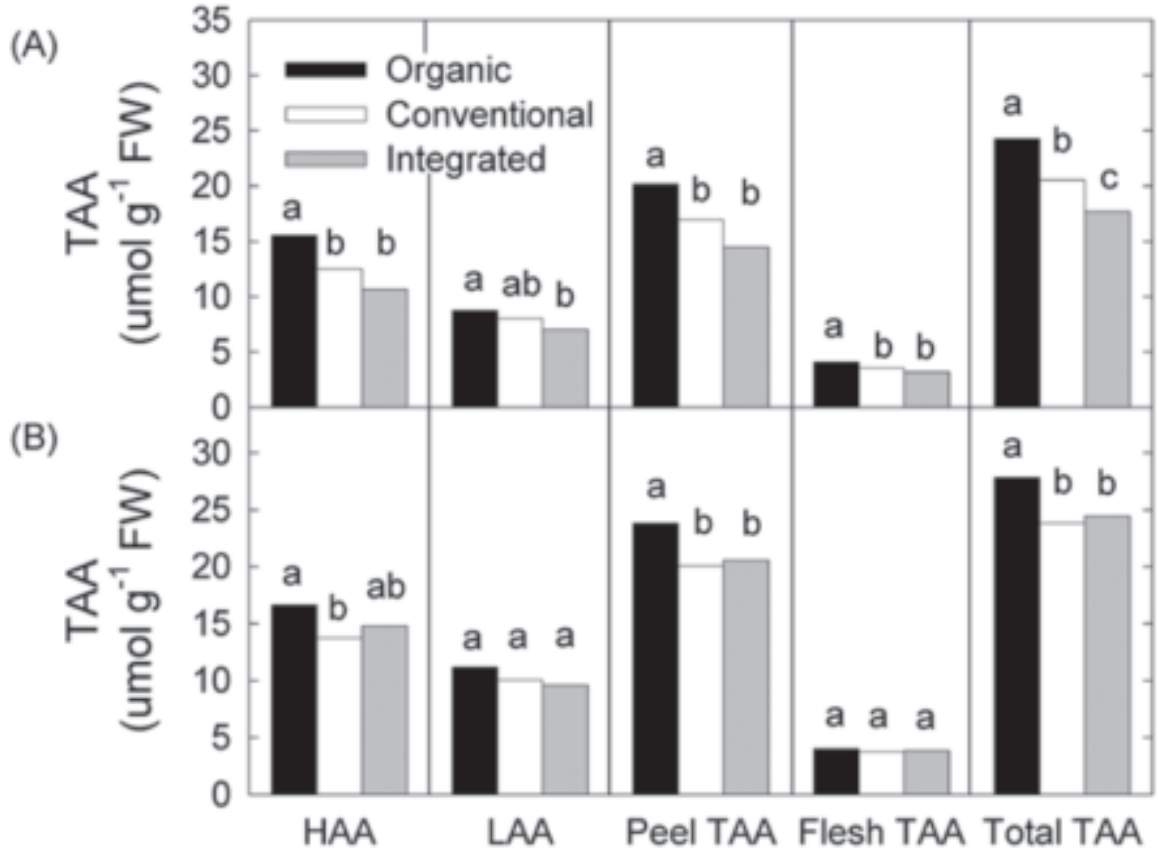

Fig. 3. Main effect means for hydrophilic (HAA); lipophilic (LAA); and peel, flesh, and total antioxidant activities (TAAs) of 'Gala' apples from organic, conventional, and integrated farm management systems measured at harvest and after three storage treatments in 2002 (A) and 2003 (B). Differences within a measurement among treatments followed by different letters are significant at the 0.05 level (LSD).

several weeks after postbloom chemical thinning, but this may have been too late to ensure an adequate return bloom in the ORG system (McArtney et al., 1996). Additionally, late fruit thinning may have reduced ORG tree size and in part caused smaller ORG fruit size in 2003, as delaying thinning in 'Gala' trees by four or more weeks after full bloom has been shown to significantly reduce fruit size and leaf area (McArtney et al., 1996).

The percent of unmarketable fruit in all three systems was higher than expected in a commercial orchard, possibly because all apples were harvested regardless of visible damage (e.g., bird peck, sunscald, severe russeting), whereas in a commercial operation many of the damaged fruit would have been discarded. In an earlier report from this study (Reganold et al., 2001), no differences in pest or disease damage were observed. However, reports from California indicated that more pest damage occurred in organic apple orchards (Caprile et al., 1994; Vossen et al., 1994).

Fertilizer applications and $\mathrm{N}$ status were other likely causes affecting yield and tree size differences in this study. In June 2000, calcium nitrate was banded in the tree rows of the CON and INT systems at a rate of $39.4 \mathrm{~kg} \mathrm{~N} / \mathrm{ha}$, when the newly grafted trees would have benefited from $\mathrm{N}$ fertilization (Neilsen et al., 2001). Due to economic constraints, the ORG system did not receive a $\mathrm{N}$ application between 1995 and Spring 2003 (Reganold et al., 2001). The ability to apply more readily available forms of $\mathrm{N}$ in synthetic fertilizers likely favored the CON and INT systems, since organically certified fertilizers, such as composted manures, are bulky and difficult to apply in orchards without specialized equipment or sufficient labor. The weed cover that often existed in the ORG plots, while possibly reducing yields and tree growth via $\mathrm{N}$ competition, may also have benefited fruit quality (Merwin and Stiles, 1994; Neilsen et al., 1999).

Zinc is commonly applied to apple orchards in Washington as a prebloom foliar spray, as it is deficient in most soils in this region (Martin, 2004). From 1997 to 2002, Zn was foliar applied to CON and INT trees, but not to ORG trees due to lack of product availability. $\mathrm{Zn}$ deficiency interferes with flower development, fruit set and development, and the maintenance of high fruit quality in apples (Neilsen and Neilsen, 1994; Stover et al., 1999). In addition, the symptoms of $\mathrm{Zn}$ deficiency seen in the ORG system have been correlated with yield reductions and poor tree growth (Swietlik, 2002). Therefore, $\mathrm{Zn}$ deficiency may also have contributed to low ORG yields in 2002 and smaller ORG trees throughout the study. It is difficult to determine the effects of withholding B applications from the ORG system, since $\mathrm{B}$ concentrations in leaves and fruit were never below the CNR and no B-related fruit disorders were observed.

Fruit quality analysis. High fruit $\mathrm{N}$ concentrations, low $\mathrm{Ca}$ concentrations, high fruit $\mathrm{N}$ :Ca ratios, increased ethylene production, and lower moisture contents can all lead to loss of cell-to-cell adhesion and flesh firmness in apples (Johnston et al., 2002). Higher fruit $\mathrm{N}$ concentrations in $\mathrm{CON}$ and INT apples (Table 4) were related to the loss of firmness in these treatments (Table 6, Fig. 1A), while Ca concentrations were relatively equal among treatments (Table 4). Lower fruit $\mathrm{N}$ levels were related to greater firmness in the earlier years of this study (Reganold et al., 2001). The concentrations of other mineral nutrients or their ratios in the fruit (Table 4), however, were not related to differences in flesh firmness in this study (Table 6, Fig. 1A).
In most cases the IEC of ORG fruit was lower than CON and/or INT fruit in the storage treatments (Table 5), which was associated with the higher flesh firmness of ORG apples (Table 6, Fig. 1A). The lower IEC for ORG apples may result from lower $\mathrm{N}$ concentrations in ORG fruit (Table 4) (Fallahi et al., 2001), but the relationship between flesh firmness and ethylene concentrations has not been fully explained (Johnston et al., 2002). Percent moisture decreased during storage in apples from all farm management systems in 2003, but few differences were seen among systems, and none that would explain the firmness differences (Peck, 2004).

Fruit firmness is one of the most important criteria for consumers of apples and the greater firmness of the ORG fruit would be advantageous in the marketplace. This is partly why Washington requires a minimum firmness of $48.93 \mathrm{~N}$ to ship 'Gala' apples (WAC, 2003), which would result in a higher percent of marketable ORG fruit based on firmness. For example, after six months CA storage in 2002 , only $10 \%$ of ORG apples were below the firmness minimum, as opposed to $36 \%$ and $58 \%$ of CON and INT apples, respectively, that were below the minimum. This illustrates the better long-term storability of ORG apples in this study. Although no system was consistently rated higher for firmness or texture by the consumer panels, the ORG apples were always rated as firm or firmer and having equal or better texture than fruit from the other systems. CON apples were generally rated to be less firm and to have poorer texture, while INT apples were more similar to ORG apples in these criteria. Greater firmness in organic apples after storage compared to conventional and/or integrated apples was reported for 'Golden Delicious' apples (Reganold et al., 2001; Weibel et al., 2000), but not for organic 'Cortland' or 'McIntosh' apples (DeEll and Prange, 1992).

Apple flavor is principally influenced by sweetness (reflected by SSC), tartness (reflected by TA), the relative ratio of sweetness to tartness (reflected by SSC to TA), and the concentrations of volatile compounds, all of which give each cultivar its distinctive flavor. Differences in SSC among systems were usually $<1{ }^{\circ}$ Brix, which usually could not be perceived by the untrained consumer panels. The small and inconsistent differences in SSC in our study differs from other comparative studies of organic and conventional apples, where organic apples generally had higher SSC (DeEll and Prange, 1992; Reganold et al., 2001). Similarly, there were no differences in TA at harvest (Table 6), and only small and inconsistent differences after storage (Figs. 1B). Consumer panelists were unable to detect differences in tartness among samples and sometimes even rated samples with lower TA as being tarter. In other comparative studies, conventional and integrated 'Golden Delicious' apples were found to have higher TA than organic apples (Reganold et al., 2001), but no differences were measured between organic and conventional 'Cortland' or 'McIntosh' apples (DeEll and Prange, 1992). SSC to TA 
also gave inconsistent results (Table 6, Fig 1C) and proved no more predictive of consumer evaluations than SSC or TA alone.

Although higher $\mathrm{N}$ status in fruit can increase volatile production in apples (Fellman et al., 2000), in this study higher fruit $\mathrm{N}$ levels were not always associated with increased volatile production. Fruit maturity also affects volatile production, with apples producing more volatiles, particularly esters, as they approach full maturity (Fellman et al., 2000). In our study maturity measured by IEC did not always relate to volatile production (Table 5). It may be that other factors contributed to differences in volatile production. The higher total volatile production by $\mathrm{CON}$ apples was not detected by the consumer panel, perhaps because the more fruity flavors produced by esters were within a similar perception range in fruit from all three systems, or the sweetness and tartness of the fruit masked any flavor differences. Since no clear pattern emerged for flavor and volatile parameters, the ORG and INT fruit were rated more acceptable (Table 8, Fig. 2) most likely because they were firmer and had better texture than CON apples (Tables 6 and 8, Figs. 1Aand 2). In the study of Reganold et al. (2001), consumers rated organic apples to be sweeter after 6 months of CA storage and integrated apples to have better flavor even though differences in overall acceptability were indistinguishable. Sensory panels found that organic 'McIntosh' apples were firmer at harvest than conventional apples but not out of storage (DeEll and Prange, 1992), perhaps due to the poor storability of this cultivar.

Few studies have examined the effects of farm management practices on fruit antioxidants, but it is known that ultraviolet radiation, low temperatures, nutrient deficiencies, and pest and pathogen attacks induce the production of antioxidants in plants (Matsuki, 1996). There was significantly more overall pest damage in the ORG system in 2003, but not in 2002 (Peck, 2004), so the higher TAA of ORG fruit could not be attributed to insect $\times$ plant interactions. Since other factors that have been shown to increase antioxidants, including lower crop loads (Stopar et al., 2002), exposure of fruit to solar radiation (Reay and Lancaster, 2001), and increased soil organic matter from compost additions (Wang and Lin, 2003), varied between years in our study, no conclusive effects could be attributed to these factors. Nevertheless, the less dense canopies of the smaller ORG trees probably resulted in more exposure to ultraviolet radiation by the fruit. A plausible explanation for the higher TAA of ORG fruit is that glyphosate, applied only to CON and INT plots, inhibited an essential enzyme, 5enolpyruvyl skimimate-3-phosphate synthase, in the flavonoid biosynthetic pathway (Daniel et al., 1999; Lydon and Duke, 1989), thereby reducing TAA in CON and INT apples. This explanation requires that glyphosate or a secondary messenger be translocated from the roots to inhibit antioxidant production in the fruit. Awad and de Jager (2002) found that increased fruit $\mathrm{N}$ levels correlated with reduced flavonoid concentrations in apple skin, which also may explain the higher TAA in ORG apples in our study (Table 4, Fig. 3A-B). As with other fruit quality parameters, differences in TAA were not consistently associated with $\mathrm{N}$ status.

Regular consumption of antioxidants, including those found in apples, have preventative effects on heart disease (Copper et al., 1999a; Eberhardt et al., 2000; Knekt et al., 1996) and lung cancer (Copper et al., 1999b; Hertog et al., 1992; Knekt et al., 1997). Yet, the National Academy of Sciences' Institute of Medicine has found insufficient information to recommend a dietary reference intake for antioxidants (IOM, 1998), and so it is difficult to ascertain how great a benefit the additional TAA seen in ORG fruit would be to human health. In addition, TAA alone does not indicate the specific antioxidant compounds that are present in fruit or how the apple tissue matrix affects the bioavailability of these antioxidants during digestion.

To summarize, the ORG farm management system posed significant production challenges for crop load management, pest and weed control, and nutrient management. The biennial bearing pattern exhibited by the ORG system would have negatively impacted economic returns. Even though their color grade was similar to CON and INT apples, a smaller percentage of ORG fruit made marketable grade, largely due to their small size. Properly timed fruit thinning would likely have corrected the biennial bearing pattern in the ORG system, resulting in similar yields of marketable fruit among the systems. The smaller sized ORG trees may also have resulted in lower yields, but this may also have been corrected if an organically approved fertilizer with more available $\mathrm{N}$ had been applied when the trees were topworked to 'Gala'. Overall, ORG apples stored better than CON and INT apples, which would have allowed the ORG apples to be sold later in the marketing season when prices are generally higher. ORG apples also had more antioxidant activity, which gives weight to the argument that there are potential health benefits to eating organic fruit. $\mathrm{N}$ status of the trees may explain some of the fruit quality differences seen in this study, but $\mathrm{N}$ status was not always consistent with differences in fruit quality between the CON and INT systems. Nonetheless, the ORG system displayed the potential to grow high quality 'Gala' apples with minimal synthetic inputs soon after being top-grafted. Many of the challenges associated with organic apple production will likely be overcome as new products and technologies become available to support the expanding production of organic apples.

\section{Literature Cited}

Aigner, D.J., J. Hopkins, and R. Johansson. 2003. Beyond compliance: sustainable business practices and the bottom line. Amer. J. Agr. Econ. 85:1126-1139.

Apple Maturity Program. 1986. Apple Maturity Program handbook. Apple Maturity Progr., Wenatchee, Wash.

Arnao, M.B., A. Cano, and M. Acosta. 2001. The hydrophilic and lipophilic contributions to total antioxidant activity. Food Chem. 73:239-244.
Awad, M.A. and A. de Jager. 2002. Relationships between fruit nutrients and concentrations of flavonoids and chlorogenic acid in 'Elstar' apple skin. Scientia Hort. 92:265-276.

Baker, B.P., C.M. Benbrook, E. Groth, III, and K.L. Benbrook. 2002. Pesticide residues in conventional, integrated pest management (IPM)-grown and organic foods: insights from three U.S. data sets. Food Additives Contaminants 19:427-446.

Cano, A., J. Hernández-Ruíz, F. García-Cánovas, M. Acosta, and M.B. Arnao. 1998. An end-point method for estimation of the total antioxidant activity in plant material. Phytochem. Anal. 9:196-202.

Caprile, J., K. Klonsky, N. Mills, S. McDougall, W. Micke, and B. Van Steenwyk. 1994. Insect damage limits yield, profits of organic apples. Calif. Agr. 48:21-28.

Carbonaro, M. and M. Mattera. 2001. Polyphenoloxidase activity and polyphenol levels in organically and conventionally grown peach (Prunus persica L., cv. Regina Bianca) and pear (Pyrus communis L., cv. Williams). Food Chem. 72:419-424.

Carbonaro, M., M. Mattera, S. Nicoli, P. Bergamo, and M. Cappelloni. 2002. Modulation of antioxidant compounds in organic vs. conventional fruit (peach, Prunus persica L., and pear, Pyrus communis L.). J. Agr. Food Chem. 50:5458-5462.

Copper, D.A., A.L. Eldridge, and J.C. Peters. 1999a. Dietary carotenoids and certain cancers, heart disease, and age-related macular degeneration: a review of recent research. Nutr. Rev. 57:201-214

Copper, D.A.,A.L. Eldridge, and J.C. Peters. 1999b. Dietary carotenoids and lung cancer: a review of recent research. Nutr. Rev. 57:133-145.

Curl, C.L., R.A. Fenske, and K. Elgethun. 2003. Organophosphorus pesticide exposure of urban and suburban pre-school children with organic and conventional diets. Environ. Health Perspectives 111:377-382.

Curl, C.L., R.A. Fenske, J.C. Kissel, J.H. Shirai, T.F. Moate, W. Griffith, G. Coronado, and B. Thompson. 2002. Evaluation of take-home organophosphorus pesticide exposure among agricultural workers and their children. Environ. Health Perspectives 110:A787-792.

Daniel, O., M.S. Meier, J. Schlatter, and P. Frischknecht. 1999. Selected phenolic compounds in cultivated plants: Ecologic functions, health implications, and modulation by pesticides. Environ. Health Perspectives Suppl. 107:109-114.

DeEll, J.R. and R.K. Prange. 1992. Postharvest quality and sensory attributes of organically and conventionally grown apples. HortScience 27:1096-1099.

DeEll, J.R. and R.K. Prange. 1993. Postharvest physiological disorders, diseases and mineral concentrations of organically and conventionally grown McIntosh and Cortland apples. Can. J. Plant Sci. 73:223-230.

Dow, A.I. 1980. Critical nutrient ranges in northwest crops. Ore. State Univ. Coop. Ext. Serv. W. Reg. Ext. Publ. 43.

Eberhardt, M.V., C.Y. Lee, and R.H. Liu. 2000 Nutrition: antioxidant activity of fresh apples. Nature 405:903-904.

Fallahi, E., W.M. Colt, C.R. Baird, B. Fallahi, and I. Chun. 2001. Influence of nitrogen and bagging on fruit quality and mineral concentrations of ' $\mathrm{BC}-2$ Fuji' apple. HortTechnology 11:462-466.

Federal Register. 1981. U.S. standards for grades of apples. Fed. Reg. 7 CFR, section 51.30051.323.

Federal Register. 2000. National Organic Program; final rule. Fed. Reg. 7 CFR, section 65.8054780596. 
Fellman, J.K., D.S. Mattinson, B.C. Bostick, J.P. Mattheis, and M.E. Patterson. 1993. Ester biosynthesis in 'Rome' apples subjected to low-oxygen atmospheres. Postharvest Biol. Biotechnol. 3:201-214.

Fellman, J.K., T.W. Miller, D.S. Mattinson, and J.P. Mattheis. 2000. Factors that influence biosynthesis of volatile flavor compounds in apple fruits. HortScience 35:1026-1034.

Fellman, J.K., D.R. Rudell, D.S. Mattinson, and J.P. Mattheis. 2003. Relationship of harvest maturity to flavor regeneration after CA storage of 'Delicious' apples. Postharvest Biol. Biotechnol. 27:39-51.

Fenske, R.A., J.C. Kissel, C. Lu, D.A. Kalman, N.J. Simcox, E.H Allen, and M.C. Keife. 2000. Biologically based pesticide dose estimates for children in an agricultural community. Environ. Health Perspectives 108:515-520.

Gavlak, R.G., D.A. Horneck, and R.O. Miller. 1994. Plant, soil and water reference methods for the western region. Univ. Alaska Coop. Ext. Serv. W. Reg. Ext. Publ. 125.

Glover, J.D., J.P. Reganold, and P.K. Andrews. 2000. Systematic method for rating soil quality of conventional, organic, and integrated apple orchards in Washington State. Agr. Ecosyst. Environ. 80:29-45.

Glover, J., H. Hinman, J. Reganold, and P. Andrews. 2002. A cost of production analysis of conventional vs. integrated vs. organic apple production systems. Wash. State Univ. Agr. Res. Ctr. Publ. XB1041.

Granatstein, D. and E. Kirby. 2002. Current trends in organic tree fruit production. Ctr. Sustaining Agr. Natural Resour. (CSANR), Wash. State Univ. Rpt. 4.

Hertog, M.G.L., P.C.H. Hollman, and M.B. Katan. 1992. Content of potentially anticarcinogenic flavonoids of 28 vegetables and 9 fruits commonly found in The Netherlands. J. Agr. Food Chem. 40:2379-2383.

Institute of Medicine. 1998. Dietary reference intakes proposed definition and plan for review of dietary antioxidants and related compounds. Inst. Med. Natl. Acad. Press, Wash., DC.

Johnston, J.W., E.W. Hewett, and M.L.A.T.M. Hertog. 2002. Postharvest softening of apple (Malus domestica) fruit: a review. N.Z. J. Crop Hort. Sci. 30:145-160.

Knekt, P., R. Järvinen, A. Reunanen, and J. Maatela. 1996. Flavonoid intake and coronary mortality in Finland: A cohort study. Brit. Med. J. 312:478-481.

Knekt, P., R. Järvinen, R. Seppänen, M. Heliövaara, L. Teppo, E. Pukkala, and A. Aromaa. 1997. Dietary flavonoids and the risk of lung cancer and other malignant neoplasms. Amer. J. Epidemiol.
$146: 223-230$

Lombardi-Boccia, G., M. Lucarini, S. Lanzi, A. Aguzzi, and M. Cappelloni. 2004. Nutrients and antioxidant molecules in yellow plums (Prunus domestica L.) from conventional and organic productions: a comparative study. J. Agr. Food Chem. 52:90-94.

Lydon, J. and S.O. Duke. 1989. Pesticide effects on secondary metabolism of higher plants. Pesticide Sci. 25:361-373.

Martin, S. (ed.). 2004. 2004 crop protection guide for tree fruits in Washington. Wash. State Univ. Coop. Ext. Serv. EB0419.

Matsuki, M. 1996. Regulation of plant phenolic synthesis: From biochemistry to ecology and evolution. Austral. J. Bot. 44:613-634.

Mattheis, J., D. Buchanan, and J. Fellman. 1998. Volatiles emitted by 'Royal Gala' apples following sequential atmosphere storage. Acta Hort. 464:201-205.

McArtney, S., J.W. Palmer, and H.M. Adams. 1996. Crop loading studies with 'Royal Gala' and 'Braeburn' apples: effects of time and level of hand thinning. N.Z. J. Crop Hort. Sci. 24:401-407.

Merwin, I.A., and W.C. Stiles. 1994. Orchard groundcover management impacts on apple tree growth and yield, and nutrient availability and uptake. J. Amer. Soc. Hort. Sci. 119:209-215.

Neilsen, G.H. and D. Neilsen. 1994. Tree fruit zinc nutrition, p. 85-99. In: A.B. Peterson and R.G. Stevens (eds.). Tree fruit nutrition: A comprehensive manual of deciduous tree fruit nutrient needs. Good Fruit Grower, Yakima, Wash.

Neilsen, G.H., E.J. Hogue, and M. Meheriuk. 1999. Nitrogen fertilization and orchard-floor vegetation management affect growth, nutrition and fruit quality of Gala apple. Can. J. Plant Sci. 79:379-385.

Neilsen, D., P. Millard, G.H. Neilsen, and E.J. Hogue. 2001. Nitrogen uptake, efficiency of use, and partitioning for growth in young apple trees. J. Amer. Soc. Hort. Sci. 126:144-150.

Nielsen, S. 1998. Food analysis. 2nd ed. Aspen Publ., Inc., Gaithersburg, Md.

Patterson, M.E. and G.W. Apel. 1984. A computer operated controlled atmosphere research facility. HortScience 19:551.

Peck, G.M. 2004. Orchard productivity and apple fruit quality of organic, conventional, and integrated farm management systems. MS thesis, Wash. State Univ., Pullman.

Peck, G.M., P.K. Andrews, C. Richter, and J.P. Reganold. 2005. Internationalization of the organic fruit market: The case of Washington State's organic apple exports to the European Union. Renewable Agr. Food Sys. 20:101-112.

Plotto, A., A.Z. Azarenko, J.P. Mattheis, and M.R.
McDaniel. 1995. 'Gala,' 'Braeburn,' and 'Fuji' apples: Maturity indices and quality after storage. Fruit Var. J. 49:133-142.

Plotto, A., M.R. McDaniel, and J.P. Mattheis. 1999. Characterization of 'Gala' apple aroma and flavor: Differences between controlled atmosphere and air storage. J. Amer. Soc. Hort. Sci. 124:416-423.

Reay, P.F. and J.E. Lancaster. 2001. Accumulation of anthocyanins and quercetin glycosides in 'Gala' and 'Royal Gala' apple fruit skin with UV-B-visible irradiation: Modifying effects of fruit maturity, fruit side, and temperature. Scientia Hort. 90:57-68.

Reganold, J.P., J.D. Glover, P.K. Andrews, and H.R. Hinman. 2001. Sustainability of three apple production systems. Nature 410:926-930.

Stopar, M., U. Bolcina, A. Vanzo, and U. Vrhovsek. 2002. Lower crop load for cv. Jonagold apples (Malus $\times$ domestica Borkh.) increases polyphenol content and fruit quality. J. Agr. Food Chem. 50:1643-1646.

Stover, E., M. Fargione, R. Risio, W. Stiles, and K. Iungerman. 1999. Prebloom foliar boron, zinc, and urea applications enhance cropping of some 'Empire' and 'McIntosh' apple orchards in New York. HortScience 34:210-214.

Swezey, S.L., M.R. Werner, M. Buchanan, and J. Allison. 1998. Comparison of conventional and organic apple production systems during three years of conversion to organic management in coastal California. Amer. J. Alt. Agr. 13:162-180.

Swietlik, D. 2002. Zinc nutrition of fruit crops. HortTechnology 12:45-50.

Vossen, P., D. Jolly, R. Meyer, L. Varela, and S. Blodgett. 1994. Disease, insect management pressures make organic production risky in Sonoma County. Calif. Agr. 48:29-36.

WAC. 2003. Standards for apples marketed within the State of Washington. Wash. Admin. Code (WAC) section 403:140-403, 255.

Wang, S. and H. Lin. 2003. Compost as a soil supplement increases the level of antioxidant compounds and oxygen radical absorbance capacity in strawberries. J. Agr. Food Chem. 51:6844-6850.

Werner, M. 1997. Soil quality characteristics during conversion to organic orchard management. Appl. Soil Ecol. 5:151-167.

Weibel, F.P., R. Bickel, S. Leuthold, and T. Alföldi. 2000. Are organically grown apples tastier and healthier? A comparative field study using conventional and alternative methods to measure fruit quality. Acta Hort. 517:417-426.

Washington State Department of Agriculture. 2004. Organic food. Wash. State Dept. Agr., Olympia. 20 June 2005. http://agr.wa.gov/FoodAnimal/Organic/default.htm\#OrganicFoodProgram. 